\title{
Association of polymorphisms of vasoactive intestinal peptide and its receptor with reproductive traits of turkey hens
}

\author{
L. Hosseinpour ${ }^{1}$, S. Nikbin ${ }^{1 \#}$, N. Hedayat-Evrigh ${ }^{1}$ \& G. Elyasi-Zarringhabaie ${ }^{2}$ \\ ${ }^{1}$ Department of Animal Science, Faculty of Agriculture, University of Mohaghegh Ardabili, Ardabil, Iran \\ ${ }^{2}$ East Azarbaijan Agricultural and Natural Resources Research and Education Center, Animal Science Research \\ Institute of Iran, Agricultural Research, Education and Extension Organization (AREEO), Tabriz, Iran
}

(Received 26 February 2018, Accepted 21 May 2019, First published online 31 May 2020)

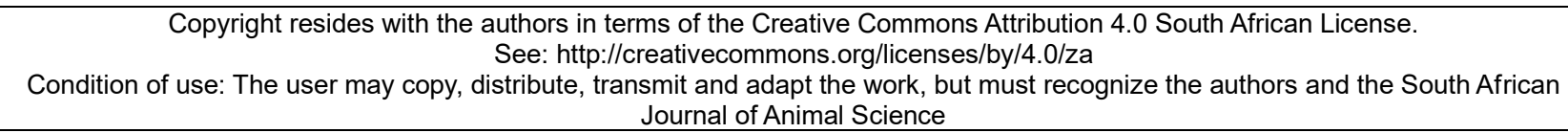
Journal of Animal Science

\begin{abstract}
The aim of this study was to identify variations of vasoactive intestinal peptide (VIP) and VIP receptor1 (VIPR-1) genes that might be associated with turkey reproductive traits. One hundred twenty turkey hens were recorded for age at first egg (AFE), first egg weight (FEW), egg number (EN), total egg weight (TEW), laying period (LP), and broodiness. The DNA was isolated from blood samples and subjected to PCR amplification of the meleagrine VIP and VIPR-1 genes. The SNPs were detected by single-strand conformation polymorphism and the variant DNA fragments were sequenced. One mutation in 3'-UTR of VIP (G5846A) and two SNPs in intron 2 of VIPR-1 (C17687T and A17690T) were found, all of them novel. The associations of the three detected SNPs with the reproductive traits of turkeys were evaluated. The detected polymorphisms were used for marker-trait association analyses. The results of association analysis showed that G5846A on 3' UTR of VIP has a significant association with LP, EN, TEW, and AFE. The G allele of G5846A was the favourable SNP allele for LP, EN, and TEW traits. The AA genotype of A17690T on intron 2 of VIPR-1 was significantly associated with higher LP, EN, and TEW. AGAA haplotype showed association with higher EN and TEW. These results suggest that the SNPs in 3'-UTR of VIP and intron 2 of VIPR-1 genes may influence egg production traits in turkey hens.
\end{abstract}

\footnotetext{
Keywords: broodiness, candidate gene, egg production, single nucleotide polymorphism, VIPR-1

"Corresponding author: snikbin@uma.ac.ir
}

\section{Introduction}

Reproduction traits have been of primary interest to breeders in the poultry industry. Many environmental factors such as photoperiod and nutritional diet (Liu, 2004; Lewis \& Gous, 2006) can affect reproduction performance, and genetic factors also influence these traits (Miazi et al., 2012; Nikbin et al., 2018; Zhu et al., 2018). It has been shown that immunization against vasoactive intestinal peptide (VIP) inhibits reproduction via neuronal and hormonal pathways (Son et al., 2016; Vistoropsky et al., 2016). The effects of VIP and its receptor (VIPR-1) genes on the reproduction traits of poultry have recently been a focus of interest (Xu et al., 2011; Ngu et al., 2015; Pu et al., 2016).

VIP is a 28-amino acid polypeptide that belongs to a family of regulating peptides such as secretin (Sheward et al., 1995). VIP is a prolactin (PRL)-releasing factor that can promote the secretion of PRL (EI Halawani et al., 1990; Kansaku et al., 2016). VIP antibody injection inhibits broodiness and reduces serum PRL in incubating hens (Sharp et al., 1998). Active immunization against VIP in turkey hens terminates broodiness and increases egg production (El Halawani et al., 2000). The VIP gene is located on chromosome 2 of turkey and has 6 exons (NCBI ref no: NC_015012.2). The association of VIP and VIPR-1 polymorphisms with egg production of chicken has been reviewed (Xu et al., 2011; Pu et al., 2016).

VIP induces its effects by interacting with its specific receptor, namely intestinal peptide receptor-1 (VIPR-1), which is located on the membrane surface of the anterior pituitary cells in birds (El Halawani et al., 1990). VIPR-1 is a glycoprotein, and belongs to the class II subfamily of the 7-transmembrane G-proteincoupled receptors superfamily (Gaudin et al., 1998). Xu et al. (2011) reported that VIP and its receptor affect 
reproduction traits of poultry via influencing gonadotropin releasing hormone $(\mathrm{GnRH})$ secretion. It has been proved that the VIPR-1 gene influences the endocrine mechanism of broodiness and, hence, involves the regulation of broodiness in avian species. (Kansaku et al., 2001; Chaiseha et al., 2004). Although the expression of the VIPR-1 gene occurs in both the hypothalamus and the pituitary, only the variation of its mRNA expression in the pituitary has been associated with reproductive traits (Chaiseha et al., 2004). You et al. (2001) stated that variation in the expression of VIPR-1 is associated with changes in the reproductive traits of egg-laying quail. Although several research projects have studied the effects of VIP and VIPR-1 expressions at transcriptional level (Chaiseha et al., 2004; Kansaku et al., 2001; You et al., 2001) and translational level (El Halawani et al., 2000; Kang et al., 2002) on reproductive traits of avians, studies on the influences of VIP and VIPR-1 DNA variations on reproductive traits of turkey hens are scarce. Indigenous turkeys of Iran have relatively low reproductive performance. To develop an indigenous turkey industry, the reproductive traits of the turkeys must be improved. The objective of this study is therefore to investigate the polymorphism of turkeys' VIP and VIPR-1 genes and their association with reproductive traits, including AFE, EN, EW, LP and broodiness behaviour of the native turkey of northwest Iran.

\section{Materials and Methods}

In this research, 120 turkey hens were used from the turkey research station of north-western Iran. Genomic DNA was extracted from the whole blood of the turkeys according to a modified protocol of Bailes et al. (2007). Reproductive traits, including egg number (EN), age at first egg (AFE), first egg weight (FEW), total egg weight (TEW), egg weight (EW), laying period (LP), and broodiness behaviour, were recorded from the turkey hens. All of the hens were kept in individual cages. Duration of laying was recorded as laying period. All laid eggs were counted and weighed to provide EN and TEW records, respectively. The hens that showed broodiness behaviour after a few layings were recorded as broody hens. The duration of the recording was from 10 March to 15 October. All recording and blood sample collections were performed in accordance with the protocol approved by the Animal Welfare Committee of University of Mohaghegh Ardabili.

Two pairs of primers were designed by Primer3 v. 0.4.0 software (Koressaar \& Remm, 2007; Untergasser et al., 2012) based on the sequence of VIP (GenBank NC_015012.2.1) and VIPR (GenBank XM_019616272.1) genes. The designed primers F: 5'- tgaaggacacctagcaaactc $-3^{\prime}$ and R: 5'acttcacacgttctcttgctc $-3^{\prime}$ ' were used to amplify exon 6 and 3'-UTR of the VIP gene (VIPe6). To amplify exon 2 and a part of intron 2 of the VIPR gene (VIPRe2), the forward and reverse primers were designed as F: $5^{\prime}$ tcccccaggttgcagaag $-3^{\prime}$ and R: 5'- tgcagaatcgtggagatgtg $-3^{\prime}$. The targeted fragments were 433 and 316 bp for VIPe6 and VIPRe2, respectively. Polymerase chain reaction (PCR) was performed in a reaction volume of $25 \mu \mathrm{L}$ containing $50-100 \mathrm{ng}$ of the genomic DNA, $12.5 \mu \mathrm{L}$ PCR Mastermix (Cinnagen, Iran), $1 \mu \mathrm{L}$ of $10 \mu \mathrm{M}$ of each primer and $2 \mu \mathrm{L} 10 \mathrm{mM}$ dNTPs, and $8.1 \mu \mathrm{L} \mathrm{ddH}_{2} \mathrm{O}$. The PCR program that was used was 5 min predenaturation at $95{ }^{\circ} \mathrm{C}$; 32 amplification cycles of $95{ }^{\circ} \mathrm{C}$ for 30 seconds; $59.5^{\circ} \mathrm{C}$ for 30 seconds; $72{ }^{\circ} \mathrm{C}$ for 1 $\mathrm{min}$; and final extension at $72{ }^{\circ} \mathrm{C}$ for $10 \mathrm{~min}$. The PCR products were examined by electrophoresis on $1.5 \%$ agarose gel stained by GelRed® nucleic acid gel stain (Biotium Inc, Hayward, CA).

To identify polymorphisms for each gene, the single-strand conformation polymorphism (SSCP) method was performed. The PCR products were electrophoresed on $8 \%$ polyacrylamide gel and the bands were visualized using the silver staining method. The PCR products of patterns that were obtained for each locus were sequenced commercially (Macrogen, South Korea).

BioEdit software (Hall, 1999) was used to align the sequences of patterns for each locus to find polymorphisms. PopGen32 software was used (Yeh et al., 2000) to identify genotype and allele frequencies of the candidate genes and Hardy-Weinberg equilibrium (HWE., The association of polymorphisms or haplotypes with the traits was analysed using SAS GLM procedure (SAS Institute Inc., Cary, NC, USA). Multiple comparisons of Tukey's test were performed for means separation. The $\mathrm{X} 2$ distribution test was performed for broodiness trait for each biallelic locus.

\section{Results}

The descriptive statistics of the recorded traits of the turkey hens are shown in Table 1. 
Table 1 Descriptive statistics of reproductive traits of turkey hens

\begin{tabular}{lcccc}
\hline Traits & Mean & se & Min & Max \\
\hline Laying period (day) & 136.09 & 4.94 & 38 & 201 \\
Egg number & 50.81 & 2.19 & 13 & 90 \\
First egg weight (gr) & 72.46 & 0.73 & 61.4 & 86.1 \\
Total egg weight (gr) & 3940.05 & 180.66 & 1000.7 & 6982.2 \\
Age at first egg (day) & 246.94 & 0.86 & 240 & 281 \\
Egg weight (gr) & 76.8 & 0.51 & 66.8 & 86.5 \\
\hline
\end{tabular}

The identified SNPs of VIPe6 and VIPRe2 are shown in Figure 1. A substitution of G with A was detected in VIPe6 at position 5846 bp (G5846A), which occurred in 3'-UTR region of the VIP gene.

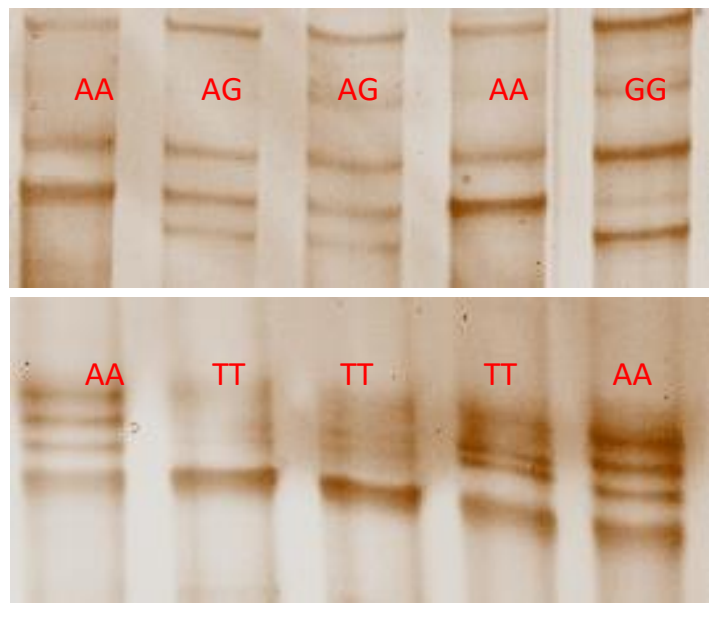

(a)

(b)

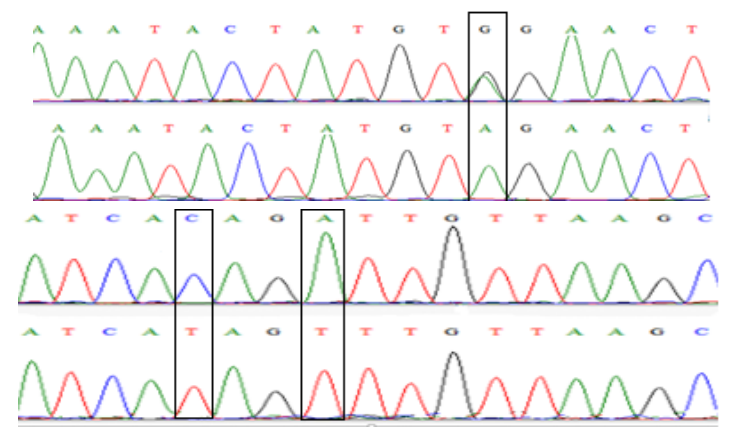

(c)

(d)

Figure 1 Polyacrylamide gel image and genotypes of (a) VIPe6, and (b) VIPRe2, and sequence electropherograms showing SNP sites (c): G5846A for VIPe6, and (d): C17687T and A17690T for VIPRe2

A transition in position of $17687 \mathrm{bp}$ (C17687T) and a transversion in position of $17690 \mathrm{bp}$ (A17690T) were detected in intron 2 of VIPR gene. Both sequences were submitted to NCBI GenBank. Accession numbers for VIPRe2 were MG770236-MG770237 and for VIPe6 were MG770238-MG770239. Allele and genotype frequencies of VIPe6 and VIPRe2 loci are presented in Table 2. Three genotypes were observed for VIPe6, and two genotypes were observed for VIPRe2. The highest genotype frequency was detected for AA of VIPe6 (0.85), while GG of VIPe6 was the lowest (0.04). Observed heterozygosity of VIPe6 was 0.11 , and no heterozygous genotype was observed for VIPRe2. The effective number of alleles per loci were 1.2532 and 1.4751 for VIPe6 and VIPRe2, respectively. The results of chi-square test revealed significant deviations from Hardy-Weinberg equilibrium (HWE) for both loci (Table 2). 
Table 2 Genotype and allele frequencies, effective number of allele and Hardy-Weinberg equilibrium test for the polymorphic loci in the turkey hens.

\begin{tabular}{|c|c|c|c|c|c|c|c|c|c|c|}
\hline \multirow[t]{2}{*}{ Locus } & \multirow[t]{2}{*}{$n_{a}$} & \multirow[t]{2}{*}{$n_{e}$} & \multicolumn{2}{|c|}{ Allele frequency } & \multicolumn{3}{|c|}{$\begin{array}{l}\text { Genotype } \\
\text { frequency }\end{array}$} & $\begin{array}{c}\text { Expected } \\
\text { heterozygosity }\end{array}$ & $\mathrm{Nei}$ & $\begin{array}{l}\text { HWE } \\
\text { Test }\end{array}$ \\
\hline & & & A & G & AA & $A G$ & GG & 017 & & \\
\hline \multirow[t]{2}{*}{ VIPe6 } & 2 & 1.25 & 0.905 & 0.095 & 0.85 & 0.11 & 0.04 & 0.17 & 0.17 & ** \\
\hline & & & A & $\mathrm{T}$ & AA & AT & TT & 320 & & \\
\hline VIPRe2 & 2 & 1.48 & 0.202 & 0.798 & 0.20 & 0.00 & 0.80 & 0.32 & 0.32 & ** \\
\hline
\end{tabular}

$\mathrm{n}_{\mathrm{a}}$ : number of alleles; $\mathrm{n}_{\mathrm{e}}$ : effective number of alleles, HWE: Hardy-Weinberg equilibrium

${ }^{*}$ significant difference from equilibrium

The results of association analysis are presented in Table 3. The statistical analysis revealed that G5846A on the 3'-UTR region of VIP gene has associations with EN, TEW, and AFE $(P<0.05)$. No significant association of G5846A with LP, FEW, or EW was found. The GG genotype of VIPe6 was associated with higher LP and AFE $(P<0.05)$. However, AG was a favourable genotype for EN and TEW traits compared with those of the AA genotype, while no significant difference was observed between the $A G$ and GG genotypes for EN and TEW.

The AA genotype of VIPRe2 was associated with greater LP, EN, and TEW $(P<0.05)$. No significant association of A17690T with AFE, FEW, and EW was found. The sequencing results showed four haplotypes for the turkeys. The haplotypes' association results are presented in Table 3 . The haplotype AAAG was favourably associated with EN and TEW. The AAGG turkeys showed later puberty and had higher AFE compared to the other haplotypes $(P<0.05)$. The results of chi-square analysis revealed that none of the polymorphisms on VIPe6 and VIPRe2 was associated with the broodiness of the turkeys.

Table 3 Association of VIPe6 and VIPRe2 genes and the haplotypes with egg production traits of indigenous turkey hens

\begin{tabular}{|c|c|c|c|c|c|c|c|}
\hline & Genotype & $\begin{array}{l}\text { Laying } \\
\text { period }\end{array}$ & $\begin{array}{c}\text { Egg } \\
\text { number }\end{array}$ & $\begin{array}{c}\text { First egg } \\
\text { weight }\end{array}$ & $\begin{array}{c}\text { Total egg } \\
\text { weight }\end{array}$ & $\begin{array}{c}\text { Age at } \\
\text { first egg }\end{array}$ & $\begin{array}{c}\text { Egg } \\
\text { weight }\end{array}$ \\
\hline \multirow{4}{*}{$\frac{5}{8}$} & AA & $133.61^{b} \pm 4.13$ & $48.55^{\mathrm{b}} \pm 1.81$ & $72.3 \pm 0.59$ & $3786.25^{b} \pm 150.24$ & $246.28^{b} \pm 0.67$ & $76.67 \pm 0.4$ \\
\hline & $A G$ & $149.91^{b} \pm 10.92$ & $65.55^{\mathrm{a}} \pm 4.93$ & $72.13 \pm 1.57$ & $5121.15^{\mathrm{a}} \pm 397.5$ & $245.82^{b} \pm 1.77$ & $77.9 \pm 1.07$ \\
\hline & $\mathrm{GG}$ & $155.75^{\mathrm{a}} \pm 18.11$ & $61.50^{\mathrm{ab}} \pm 8.18$ & $71.55 \pm 2.6$ & $4602.5^{\mathrm{ab}} \pm 659.18$ & $261.75^{a} \pm 2.92$ & $74.88 \pm 2.6$ \\
\hline & $P$-value & 0.2151 & 0.0032 & 0.9588 & 0.0061 & 0.0001 & 0.32 \\
\hline \multirow{3}{*}{ 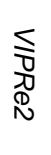 } & $\mathrm{TT}$ & $131.92^{b} \pm 3.59$ & $47.79^{b} \pm 1.66$ & $72.65 \pm 0.55$ & $3687.0^{b} \pm 132.12$ & $246.58 \pm 0.68$ & $76.78 \pm 0.37$ \\
\hline & $\mathrm{AA}$ & $151.79^{a} \pm 7.85$ & $62.26^{a} \pm 3.27$ & $72.80 \pm 1.21$ & $4819.59^{a} \pm 289.15$ & $248.89 \pm 1.49$ & $77.24 \pm 0.8$ \\
\hline & $P$-value & 0.023 & 0.0001 & 0.9077 & 0.0005 & 0.16 & 0.596 \\
\hline \multirow{5}{*}{$\begin{array}{l}\frac{T}{80} \\
\frac{0}{0} \\
\frac{1}{0} \\
\frac{0}{2}\end{array}$} & TTAA & $132.7 \pm 4.46$ & $48.22^{b} \pm 2.02$ & $72.19 \pm 0.62$ & $3744.5^{\mathrm{b}} \pm 162.1$ & $246.34^{b} \pm 0.72$ & $76.83 \pm 0.4$ \\
\hline & AAAA & $145.5 \pm 18.39$ & $54.00^{\mathrm{ab}} \pm 8.34$ & $72.92 \pm 2.52$ & $4207.4^{b} \pm 668.36$ & $244.5^{\mathrm{b}} \pm 2.98$ & $77.8 \pm 1.77$ \\
\hline & AAAG & $149.9 \pm 11.08$ & $65.55^{\mathrm{a}} \pm 5.03$ & $72.13 \pm 1.54$ & $5121.1^{a} \pm 403.04$ & $245.81^{b} \pm 1.8$ & $77.9 \pm 1.07$ \\
\hline & AAGG & $163.25 \pm 18.39$ & $61.5^{\mathrm{ab}} \pm 8.34$ & $71.55 \pm 2.56$ & $4602.5^{\mathrm{b}} \pm 668.36$ & $261.75^{a} \pm 2.98$ & $74.87 \pm 1.8$ \\
\hline & $P$-value & 0.22 & 0.01 & 0.55 & 0.015 & 0.0001 & 0.49 \\
\hline
\end{tabular}

Data are expressed as mean \pm SD. Within a row values followed by different letters differ significantly at the 0.05 level by the Tukey test

\section{Discussion}

In the present study, both VIPe 6 and VIPRe2 gene regions showed polymorphisms. This is the first report for the SNP in the 3'-UTR region of avian VIP. The number of reports in this region is limited. VIP/Apol (Xu et al., 2011), VIP/Hinfl, and VIP/Vspl (Vu \& Ngu, 2016) have been reported in chickens, but were not 
matched with the current findings on 3'-UTR region of VIP in turkey. Differences in SNPs between the two species in the same region of the gene might be due to different evolutionary processes with different rates of mutation on the orthologues in the different species. Most of the turkeys had the AA genotype. However, only a low frequency (9\%) of G allele was observed. Therefore, the homozygote GG appeared rarely (4\%) in this study.

In VIPRe2, both detected SNPs (C17687T and A17690T) were novel and have never been reported in turkeys. Only two haplotypes were detected for VIPRe2 in the turkeys. Since no similar work on this gene has been found, the frequencies of the alleles at these loci were not available for comparison. However, Zhou et al. (2008) stated that there are seven variation sites in the region from exon 6 to exon 11 in chickens. Two more SNPs were reported by Pu et al. (2016) in exon 4 (G373T) and exon 6 (A313G) of laying quail. Chicken VIPR1/Tail, VIPR1/Hahl, and VIPR1/Taql polymorphisms (Vu \& Ngu, 2016; Xu et al., 2011) did not match with SNPs of VIPRe2 of the present study either.

In this research, the polymorphic loci were not in HWE. This may have happened because of factors such as selection, mutation, and/or migration, which influence allele and genotype frequencies through generations (Falconer \& Mackay, 1996). Since the population was under selection, immigration of new males, and deviation from HWE were predictable.

The current research is the first attempt to investigate the relationship of the VIP and VIPR-1 loci polymorphism with reproductive traits in turkey. Replacing the allele A with the allele $G$ of VIPe6 was a synonymous mutation. Substituting $A$ with $G$ significantly increased $E N$ and TEW in AG hens. The GG genotype also showed longer LP. These results showed that the $G$ allele was the favourable allele for LP, EN, and TEW traits. However, it was also associated with higher AFE in the turkey hens. Although the mutation of 3'-UTR has no effect on the amino acid sequence of the related protein, it may alter the appropriate expression of the VIP gene. It was revealed that SNP in 3'-UTR can be associated with phenotype changes via altering expression of the gene responsible for the phenotype (Yue et al., 2017; Zhang et al., 2016). Many studies have proved that SNPs in 3'-UTR may regulate expression of their genes (Reamon-Buettner et al., 2007; Kataoka et al., 2016; Zuo et al., 2014). Changes in the 3'-UTR sequence are significantly associated with mRNA stability (Kamiyama et al., 2007) and could influence the rates of localization, translation, and mRNA degradation (Reamon-Buettner et al., 2007). Recent studies revealed that miRNA reacts with $3^{\prime}$-UTR of mRNA, which may negatively regulate the gene transcripts and, consequently, alter the related protein synthesis (Dumortier \& Obberghen, 2012; Egervari et al., 2016). Additionally, it may influence adenylation of 3'-UTR and/or cleavage, which accordingly affects gene expression (Liu et al., 2010; Skeeles et al., 2013). The importance of the SNPs in 3'-UTR and its effect on the regulation of the gene expression cannot be ignored. Therefore, the substitution of G5846A might influence the VIP gene expression through this way, and thus the reproductive traits of the turkey hens. Zhou et al. (2010) reported a significant association between a polymorphism of intron 2 of the chicken VIP and egg numbers from 90 to 300 days old, and AFE.

Prolactin gene expression and its plasma concentrations are influenced by VIP levels in the anterior pituitary gland (Chaiseha et al., 2004; Kansaku et al., 2001). Since prolactin affects egg production and serum oestrogen level (Zhang et al., 2007), its influence of VIP level on egg production traits can be explained. Meek et al. (2016) reported that VIP increased the level of pepsinogen secretion from the stomach by affecting the parasympathetic nerves, which resulted in improved digestion and indirectly increased the energy, protein, and minerals that are required for egg production. This can also affect the total weight of the egg produced during a period by maintaining the chicken's physiological condition (Bu et al., 2015; Van Emous et al., 2015). On the other hand, the VIP gene stimulates growth hormone releasing hormone $(\mathrm{GHRH})$ secretion by stimulating the secretion of ghrelin. The secretion of GHRH causes the release of growth hormone (Osterstock et al., 2010). Consequently, growth hormone increases follicles and egg production in poultry (Pitts et al., 1996).

The effect of VIP on GnRH via the VIP receptors in species of both mammals and poultry was reported (Christian \& Moenter, 2008), such that VIP and its receptor, which affect GnRH, can reduce AFE in poultry (Xu et al., 2011). It may explain how G5846A is responsible as an effective SNP on LP, EN, TEW, and AFT traits.

Although this SNP has never previously been reported, similar to the current result, other polymorphisms of VIP showed significant influence on EN of chickens. Zhou et al. (2010) revealed that the VIP/Vsp/ SNP associated with EN from 90 to 300 days of age and that VIP/Hinfl influenced broodiness in chickens. Xu et al. (2011) also reported three polymorphisms, VIP/Apol, VIPR1/Taql, and VIPR1/Hhal, associated with egg number at 300 days old.

A17690T and C17687T SNPs in VIPRe2 have not previously been reported. Based on the current results, the two SNPs were close together. However, the authors found only one haplotype. Therefore, they regarded them as one allele (A17690T) in statistical analysis. Different haplotypes from the two SNPs may 
be identified in larger populations. The A allele was a favourable allele for LP, EN, and TEW. The allele was located in intron 2. Since the SNP was detected in the intron region, it would not cause any change in the sequence of the protein. However, the SNPs in the intron region may affect transcription of the gene (Berulava \& Horsthemke, 2010) and consequently influence the level of VIPR. Olivier (2004) suggested that intronic SNP may affect the level of expression of the gene. There are many reports about significant association between intron regions and phenotypes (Anh et al., 2015; Berkowicz et al., 2012; Luna-Nevarez et al., 2011). Other reports also indicated that any change in the intronic region was effective on the splicing process, and consequently influenced the gene expression level (Komar, 2007). Several research articles have been published about the potential effects of splicing on the trait phenotype (Faustino \& Cooper, 2003; Ho et al., 2011; Nissim-Rafinia \& Kerem, 2002). Therefore, the SNP in intron 2 may change the expression level of the VIPR-1 gene and then influence the phenotypes.

VIPR-1 is distributed widely in the gastrointestinal tract, genitourinary system, and other smooth muscle and secreting glands. By binding to the G protein, VIPR-1 activates adenylyl cyclase and increases cAMP (Ishihara et al., 1992). Therefore, VIPR-1 indirectly affects the activity of digestive gland cells and consequently increases the digestive enzymes, improves feed efficiency, and thus increases egg production in turkeys. The effect of VIP on gonadotropin-releasing hormone via VIPR-1 (Christian \& Moenter, 2008) can influence levels of gonadotropins and, as a result, the reproductive performance of turkeys. The expression of the VIPR-1 gene showed a positive correlation with broodiness in chickens and turkeys, which affects egg production directly (You et al., 2001). Several studies have shown association between VIPR-1 gene polymorphisms and reproductive traits of avian species. VIPR-1 was introduced as an MAS marker for decreasing the rate of broodiness and improving egg production (Zhou et al., 2008). Chaiseha et al. (2004) revealed that the VIPR-1 gene plays a role in regulating broodiness in birds via influence on the endocrine system. Association between polymorphisms of VIPR-1 and egg number of quail (Pu et al., 2016) and chickens (Ngu et al., 2015) has also been reported. Similarly Zhou et al. (2008) showed that VIPR-1 polymorphisms affected incubation behaviour and age at first egg significantly. Similar to the present study, Xu et al. (2011) did not find any association between the polymorphisms of VIPR-1 (VIPR-1/Hahl and VIPR$1 /$ Taq) and age at first egg in Ga Noi chickens. The statistical results revealed that the haplotype AAAG was favourably associated with EN and TEW.

VIPe6 and VIPRe2 polymorphisms did not show association with broodiness of turkeys. These results were in contrast with some reports on chickens and quail. This may occur because of the differences in SNPs and species between the present study and previous research. Although Zhou et al. (2010) demonstrated that C338T SNP in intron 2 of VIP was associated with incubation behaviour, the AGG indel in 5'-UTR did not affect broodiness in chickens. Investigation of the VIPR-1 gene of chickens revealed that $\mathrm{C}+598 \mathrm{~T}$ in intron 2 is associated with frequency of broodiness, but VIPR-1 was found to have no effect on broodiness frequency (Zhou et al., 2008).

\section{Conclusion}

Three novel SNPs were found (one SNP in 3'-UTR of VIP and two SNPs in intron 2 of VIPR-1). The results revealed that these SNPs in meleagrine VIP and VIPR-1 were associated with egg production traits, egg number, total egg weight, and laying period. The results can be used for selection and breeding programmes, to improve the reproductive performance of turkey hens. The effects of the SNPs on the expression level of the VIP and VIPR-1 genes require further investigation.

\section{Acknowledgements} Ardabili.

This work was supported by the Vice-Chancellor for Research and Technology of University of Mohaghegh

\section{Authors' Contributions}

SN planed the research, supervised its conduct and wrote the manuscript. GE-Z carried out recording and sampling. LH carried out the lab experiments and prepared the data. SN and NH-E supervised preparation of materials and data analysis. All authors have read and approved the manuscript.

\section{Conflict of interest declaration}

The authors declare that they have no conflict of interest.

\section{References}

Anh, N.T.L., Kunhareang, S. \& Duangjinda, M., 2015. Association of chicken growth hormones and insulin-like growth factor gene polymorphisms with growth performance and carcass traits in Thai broilers. Asian-Australas. J. Anim. Sci. 28(12), 1686-1695. 
Bailes, S.M., Devers, JJ, Kirby, J.D. \& Rhoads, D.D., 2007. An inexpensive, simple protocol for DNA isolation from blood for high-throughput genotyping by polymerase chain reaction or restriction endonuclease digestion. Poult. Sci. 86,102-106.

Berkowicz, E.W., Magee, D.A., Berry, D.P., Sikora, K.M., Howard, D.J., Mullen, M.P. \& MacHugh, D.E., 2012. Single nucleotide polymorphisms in the imprinted bovine insulin-like growth factor 2 receptor gene (IGF2R) are associated with body size traits in Irish Holstein-Friesian cattle. Anim. Genet. 43(1), 81-87.

Berulava, T. \& Horsthemke, B., 2010. The obesity-associated SNPs in intron 1 of the FTO gene affect primary transcript levels. Eur. J. Hum. Genet. 18, 1054-1056

Bu, Z., Xie, P., Fu, S.Y., Tong, H.B. \& Dai, X., 2015. Effect of energy and protein levels on performance, egg quality, and nutrient digestibility of laying pigeons. J. Appl. Poult. Res. 24(3), 371-379.

Chaiseha, Y., Youngren, O.M. \& El Halawani, M.E., 2004. Expression of vasoactive intestinal peptide receptor messenger RNA in the hypothalamus and pituitary throughout the turkey reproductive cycle. Biol. Reprod. 70, 593-599.

Christian, C.A. \& Moenter, S.M., 2008. Vasoactive intestinal polypeptide can excite gonadotropin-releasing hormone neurons in a manner dependent on estradiol and gated by time of day. Endocrinol. 149, 3130-3136.

Dumortier, O. \& Van Obberghen, E., 2012. MicroRNAs in pancreas development. Diabetes Obes. Metab. 14, $22-28$.

Egervari, G., Jutras-Aswad, D., Landry, J., Miller, M.L., Anderson, S.A., ..., Hurd Y.L., .2016. A functional 3'UTR polymorphism (rs2235749) of prodynorphin alters microRNA-365 binding in ventral striatonigral neurons to influence novelty seeking and positive reward traits. Neuropsychopharmacol. 41, 2512-2520.

El Halawani, M.E., Whiting, S.E., Silsby, J.L., Pitts, G.R. \& Chaiseha, Y., 2000. Active immunization with vasoactive intestinal peptide in turkey hens. Poult. Sci. 79, 349-354.

El Halawani, M.E., Silsby, J.L. \& Mauro, L.J., 1990. Enhanced vasoactive intestinal peptide-induced prolactin secretion from anterior pituitary cells of incubating turkeys (Meleagris gallopavo). Gen. Comp. Endocrinol. 80, 138-145.

Falconer, D.S. \& Mackay, T.F.C., 1996. Introduction to quantitative genetics. Longmans Green, Harlow, Essex, UK.

Faustino, N.A. \& Cooper, T.A., 2003. Pre-mRNA splicing and human disease. Genes Dev. 17(4), 419-437.

Gaudin, P., Maoret, J.J., Couvineau, A., Rouyer-Fessard, C. \& Laburthe, M., 1998. Constitutive activation of the human vasoactive intestinal peptide 1 receptor, a member of the new class II family of G protein-coupled receptors. J. Biol. Chem. 273, 4990-4996.

Hall, T.A., 1999. BioEdit: A User-Friendly Biological Sequence Alignment Editor and Analysis Program for Windows 95/98/NT. Nucleic Acids Symp. Ser. 41, 95-98.

Ho, P.A., Kuhn, J., Gerbing, R.B., Pollard, J.A., Zeng, R., ..., Meshinchi, S., 2011. WT1 synonymous single nucleotide polymorphism rs16754 correlates with higher mRNA expression and predicts significantly improved outcome in favorable- risk pediatric acute myeloid leukemia: a report from the children's oncol- ogy group. J. Clin. Oncol. 29, 704-711.

Ishihara, T., Shigemoto, R., Mori, K., Takahashi, K. \& Nagata, S., 1992. Functional expression and tissue distribution of a novel receptor for vasoactive intestinal polypeptide. Neuron. 8, 811-819.

Kamiyama, M., Kobayashi, M., Araki, S., lida, A., Tsunoda, T., ..., Maeda, S., 2007. Polymorphisms in the 3' UTR in the neurocalcin delta gene affect mRNA stability, and confer susceptibility to diabetic nephropathy. Hum. Genet. 122, 397-407.

Kang, S.W., Youngren, O.M. \& El Halawani, M.E., 2002. Influence of VIP on prolactinemia in turkey anterior pituitary cells, role of cAMP second messenger in VIP-induced prolactin gene expression. Regul. Peptides. 109, 39-44.

Kansaku, N., Shimada, K., Ohkubo, T., Saito, N., Suzuki, T., Matsuda, Y. \& Zadworny, D., 2001. Molecular cloning of chicken vasoactive intestinal polypeptide receptor complementary DNA, tissue distribution and chromosomal localization. Biol. Reprod. 64, 1575-1581.

Kansaku, N., Tobari, Y., Hiyama, G., Wakui, S., Minoguchi, N., ..., Zadworny, D., 2016. Effects of vasoactive intestinal polypeptide and forskolin on mRNA expression of prolactin and prolactin regulatory element-binding protein in the anterior pituitary gland of chicken embryo and laying hens. J. Poult. Sci. 53, 313-317.

Kataoka, K., Shiraishi, Y., Takeda, Y., Sakata, S., Matsumoto, M., .., Mizuno, S., 2016. Aberrant PD-L1 expression through 3'-UTR disruption in multiple cancers. Nature 534(7607), 402.

Koressaar, T. \& Remm, M., 2007. Enhancements and modifications of primer design program Primer3. Bioinformatics. 23(10): 1289-1291.

Komar, A.A., 2007. Silent SNPs: Impact on gene function and phenotype. Pharmacogenomics 8(8), 1075-1080.

Lewis, P.D. \& Gous, R.M., 2006. Effect of final photoperiod and twenty-week body weight on sexual maturity and early egg production in broiler breeders. Poult. Sci. 85, 377-383.

Liu, H.K., Lilburn, M.S., Koyyeri, B., Anderson, J.W. \& Bacon, W.L., 2004. Preovulatory surge patterns of luteinizing hormone, progesterone, and estradiol-17 $\beta$ in broiler breeder hens fed ad libitum or restricted fed 1. Poult. Sci. 83, 823-829.

Liu, W.J., Sun, D.X., Yu, Y., Li, G., Tang, S.Q., ..., Zhang, Y., 2010. Association of Janus kinase 2 polymorphisms with growth and reproduction traits in chickens. Poult. Sci. 89, 2573-2579.

Luna-Nevarez, P., Rincon, G., Medrano, J.F., Riley, D.G., Chase, C.C., ..., Thomas, M.G., 2011. Single nucleotide polymorphisms in the growth hormone-insulin-like growth factor axis in straightbred and crossbred Angus, Brahman, and Romosinuano heifers: Population genetic analyses and association of genotypes with reproductive phenotypes. J. Anim. Sci. 89(4), 926-934.

Meek, C.L., Lewis, H.B., Reimann, F., Gribble, F.M. \& Park, A.J., 2016. The effect of bariatric surgery on gastrointestinal and pancreatic peptide hormones. Peptides 77, 28-37. 
Miazi, O.F., Miah, G., Miazi, M.M., Uddin, M.M., Hassan, M.M. \& Faridahsan, M., 2012. Fertility and hatchability of Fayoumi and Sonali chicks. Scholarly J. Agric. Sci. 2, 83-86.

Ngu, N.T., Xuan, N.T., Vu, C.T., An, N.T., Dung, T.N. \& Nhan, V.T.H., 2015. Effects of genetic polymorphisms on egg production in indigenous Noi chicken. J. of Exp. Biol. Agric. Sci. 3(6), 487-493.

Nikbin, S., Panandam, J.M,, Yaakub, H. \& Murugaiyah, M., 2018. Association of novel SNPs in gonadotropin genes with sperm quality traits of Boer goats and Boer crosses. J. Appl. Anim. Res. 46(1), 459-466.

Nissim-Rafinia, M. \& Kerem, B., 2002. Splicing regulation as a potential genetic modifier. Trends Genet. 18, $123-127$.

Olivier, M., 2004. From SNPs to function: the effect of sequence variation on gene expression. Focus on "A survey of genetic and epigenetic variation affecting human gene expression”. Physiol. Genomics. 16(2), 182-183.

Osterstock, G., Escobar, P., Mitutsova, V., Gouty-Colomer, L.A., Fontanaud, P., ..., Me ry, P.F., 2010. Ghrelin stimulation of growth hormone-releasing hormone neurons is direct in the arcuate nucleus. PLoS One. 5, e9159.

Pitts, G.R., Youngren, O.M., Phillips, R.E. \& El Halawani, M.E., 1996. Photoperiod mediates the ability of serotonin to release prolactin in the turkey. Gen. Comp. Endocr. 104, 265-272.

Pu, Y-j., Wu, Y., Xu, X-j., Du, J-P. \& Gong, Y-Z., 2016. Association of VIPR-1 gene polymorphisms and haplotypes with egg production in laying quails. J. Zhejiang Univ. Sci. B. 17(8), 591-596.

Reamon-Buettner, S.M., Cho, S-H. \& Borlak, J., 2007. Mutations in the 3'-untranslated region of GATA4 as molecular hotspots for congenital heart disease (CHD). BMC Med. Genet. 8, 38-38.

Sharp, P.J., Dawson, A. \& Lea, R.W., 1998. Control of luteinizing hormone and prolactin secretion in birds. Comparative biochemistry and physiology Part C. Pharmacol., Toxicol. Endocrinol. 119, 275-282.

Sheward, W.J., Lutz, E.M. \& Harmar, A.J., 1995. The distribution of vasoactive intestinal peptide2 receptor messenger RNA in the rat brain and pituitary gland as assessed by in situ hybridization. Neuroscience 67, 409-418.

Skeeles, L.E., Fleming, J.L., Mahler, K.L. \& Toland, A.E., 2013. The impact of 3'UTR variants on differential expression of candidate cancer susceptibility genes. PLoS One. 8, e58609.

Son, Y.L., Ubuka, T., Soga, T., Yamamoto, K., Bentley, G.E. \& Tsutsui, K., 2016. Inhibitory action of gonadotropininhibitory hormone on the signaling pathways induced by kisspeptin and vasoactive intestinal polypeptide in GnRH neuronal cell line, GT1-7. FASEB J. 30, 2198-2210.

Untergasser, A., Cutcutache, I., Koressaar, T., Ye, J., Faircloth, B.C., Remm, M. \& Rozen, S.G., 2012. Primer3--new capabilities and interfaces. Nucleic Acids Res. 40, e115.

Van Emous, R.A., Kwakkel, R.P., van Krimpen, M.M. \& Hendriks, W.H., 2015. Effects of dietary protein levels during rearing and dietary energy levels during lay on body composition and reproduction in broiler breeder females. Poult. Sci. 94(5), 1030-1042

Vistoropsky, Y., Heiblum, R., Smorodinsky, N.I. \& Barnea, A., 2016. Active immunization against vasoactive intestinal polypeptide decreases neuronal recruitment and inhibits reproduction in zebra finches. J. Comp. Neurol. 524, 2516-2528.

Vu, C.T. \& Ngu, N.T., 2016. Single nucleotide polymorphisms in candidate genes associated with egg production traits in native Noi chicken of Vietnam. IJPAES. 6, 162-169.

Xu, H., Zeng, H., Luo, C., Zhang, D., Wang, Q., ..., Zhang, X., 2011. Genetic effects of polymorphisms in candidate genes and the QTL region on chicken age at first egg. BMC Genetics. 12,33.

Yeh, F.C., Yang, R.T., Boyle, J., Ye, Z. \& Xiyan, J.M., 2000. PopGene32, Microsoft Windows-Based Freeware for Population Genetic Analysis. Version 1.32. Molecular Biology and Biotechnology Centre. University of Alberta, Edmonton, Alberta, Canada.

You, S., Hsu, C.C., Kim, H., Kho, Y., Choi, Y.J., El Halawani, M.E., Farris, J. \& Foster, D.N., 2001. Molecular cloning and expression analysis of the turkey vasoactive intestinal peptide receptor. Gen. Comp. Endocrinol. 124, 53-65.

Yue, B., Han, F., Wu, J., Wang, Y., Zhang, C., Fang, X., Qi, X., Bai, Y. \& Chen, H., 2017. Combined haplotypes of CaSR gene sequence variants and their associations with growth traits in cattle. Anim. Biotechnol. 28, 260-267.

Zhang, L., Ma, X., Xuan, J., Wang, H., Yuan, Z., ..., Du, L., 2016. Identification of MEF2B and TRHDE gene polymorphisms related to growth traits in a new ujumqin sheep population. PLoS One. 11(7),e0159504.

Zhang, X.L., Jiang, X., Liu, Y.P., Du, H.R. \& Zhu, Q., 2007. Identification of avai polymorphisms in the third intron of gh gene and their associations with abdominal fat in chickens. Poult. Sci. 86,1079-1083.

Zhou, M., Du, Y., Nie, Q., Liang, Y., Luo, C., Zeng, H. \& Zhang, X., 2010. Associations between polymorphisms in the chicken VIP gene, egg production and broody traits. Br. Poult. Sci. 51, 893-903.

Zhou, M., Lei, M., Rao, Y., Nie, Q., Zeng, H., ..., Zhang, X., 2008. Polymorphisms of vasoactive intestinal peptide receptor-1 gene and their genetic effects on broodiness in chickens. Poult. Sci. 87(5), 893-903.

Zhu, H., Qin, N., Tyasi, T.L., Jing, Y., Liu, D., Yuan, S. \& Xu, R., 2018. Genetic effects of the transcription factors-sal-like 1 and spalt-like transcription factor 3 on egg production-related traits in Chinese Dagu hens. J Exp. Zool. A. Ecol. Integr .Physiol. 329(1), 23-28.

Zuo, B., Liu, G., Peng, Y., Qian, H., Liu, J., Jiang, X. \& Mara, A., 2014. Melanocortin-4 receptor (MC4R) polymorphisms are associated with growth and meat quality traits in sheep. Mol. Biol. Rep. 41(10), 6967-6974. 